\title{
In vitro effect of the herbicide glyphosate on human blood platelet aggregation and coagulation
}

\author{
Efeito in vitro do herbicida glifosato na agregação plaquetária e coagulação sanguínea em \\ humanos
}

\author{
Teresinha de Jesus C. Neiva \\ Ana Carolina R. Moraes ${ }^{l}$ \\ Rafaella Schwyzer ${ }^{1}$ \\ Cidônia de Lourdes Vituri ${ }^{2}$ \\ Tania Rubia F. Rocha ${ }^{3}$ \\ Diana M. Fries ${ }^{3}$ \\ Márcio A. Silva \\ Aloisio Luiz Benedetti ${ }^{4}$
}

\begin{abstract}
Glyphosate [N-(phosphonomethyl)-glycine] is a broad-spectrum, non-selective, postemergence herbicide that is extensively used in agriculture. Published data referring to the effects of this product on human health are contradictory. We showed previously that long-term treatment of rats with low doses of Glyphosate-Biocarb ${ }^{\circledR}$ may induce hepatic histological changes and bleeding without decreasing platelet counts. The aim of the current study was to investigate, in vitro, the effect of glyphosate on human blood platelet aggregation and coagulation. Materials and methods: Platelet aggregation was determined in the platelet-rich plasma using the agents: $6 \mu M$-adenosine diphosphate, $6 \mu \mathrm{M}$-epinephrine and $4 \mu \mathrm{g} / \mathrm{mL}$-collagen. Pretreatment with $500 \mu \mathrm{g} / \mathrm{mL}$ glyphosate showed significant hypofunction of the three aggregating agents. The inhibitory effect was dose-dependent at concentrations from 50 to $500 \mu \mathrm{g} / \mathrm{mL}$. The release of ATP was lower for glyphosate-treated platelets after stimulation by collagen. On the other hand, glyphosate did not promote any inhibitory effects on prothrombin time, thromboplastin time and thrombin time. In conclusion, the results demonstrate that glyphosate promotes changes in the platelet metabolism with an inhibitory effect on primary hemostasis. Rev. Bras. Hematol. Hemoter. 2010;32(4):291-294.
\end{abstract}

Key words: Glyphosate; platelet aggregation; platelet secretion; blood coagulation; herbicide resistance.

\section{Introduction}

Glyphosate (GP) is the active ingredient of Biocarb $₫$ or Roundup ${ }^{\circledR}$ (Brazil), marketed as a non-selective broadspectrum, post-emergence herbicide, used against grasses, broad-leaf weeds and weeds in rice, corn and soybean plantations. ${ }^{1,2}$ The adverse effects of glyphosate and other components of its commercial formulation are periodically re-evaluated and toxicity of the pesticide has been described after severe exposure. ${ }^{3,4,5}$ It has been suggested that a particular toxicity of glyphosate-containing products is related to the surfactant components in its composition. With regular usage, several regulatory agencies and scientific institutions worldwide have concluded that there is no indication of any human health concern with glyphosate and Roundup ${ }^{\circledR} .{ }^{5}$ However, recent studies suggest that long-term exposition to glyphosate can cause toxicity in pregnant rats with deficient ossification of fetuses 6 , modifications in cell cycle activity, ${ }^{7,8}$ skin injuries, ${ }^{9}$ and increased rates of non-Hodgkin's lymphoma. ${ }^{10}$ Furthermore, we showed previously that longterm treatment of rats with low doses of Glyphosate-Biocarb ${ }^{\circledR}$ may induce hepatic histological changes, the leakage of hepatic intracellular enzymes such as alanine aminotransferase and aspartate aminotransferase as well as nasal

\footnotetext{
${ }^{1}$ Hematologia Clínica. Departamento de Análises Clínicas-CCS - Universidade Federal de Santa Catarina - Florianópolis-SC. ${ }^{2}$ Citologia Clínica. Departamento de Análises Clínicas-CCS - Universidade Federal de Santa Catarina - Florianópolis-SC.

${ }^{3}$ Hemostasia. Laboratório de Hemostasia do Hospital das Clínicas, Faculdade de Medicina da USP - São Paulo-SP.

${ }^{4}$ Biologia Celular. Laboratório de Neurobiologia e Hematologia Celular e Molecular-BEG-CCB - Universidade Federal de Santa Catarina-SC.
}

Correspondence: Teresinha de Jesus Carvalho Neiva

Department of Clinical Analysis, CCS-UFSC

88040-900 - Florianópolis-SC - Brazil

Phone number: (55 48) 3319712

E-mail address: neiva@ccs.ufsc.br

Doi:10.1590/S1516-84842010005000087 
bleeding but without decreasing platelet counts. ${ }^{11}$

The haemostatic system depends on an interaction between the blood vessel wall and platelet circulating factors. The activity developed by platelets is considered an initial response in the regulation of the hemostatic mechanism and among their most important functions are adhesion, aggregation and secretion. Furthermore, pro-coagulant proteins participate in the consolidation of the hemostatic process. On considering bleeding events previously observed in rats, we investigated possible in vitro effects of glyphosate on platelets and blood clotting.

\section{Material and Methods}

Chemicals: Adenosine diphosphate (ADP), epinephrine, collagen and luciferin/luciferase were purchased from Chronolog Corporation, USA. Thromboplastin and ellagic acid phospholipid and thrombin reagents were purchased from Sigma Diagnostics, USA.

Subjects: This study involved 10 volunteer blood donors, who signed informed consent before participating in agreement with the Ethics Committee of the University Hospital Hemotherapy Clinic-HU-UFSC.

Isolation of platelets: Nine parts of blood drawn by venipuncture were mixed with one part of $3.8 \%$ trisodium citrate. Platelet rich plasma (PRP) was prepared by centrifuging the citrated blood at room temperature for $7 \mathrm{~min}$ at $180 \mathrm{~g}$. The platelet concentration was adjusted to $3.0 \times 10^{8} \mathrm{cells} / \mathrm{mL}$ with autologous plasma.

Measurement of platelet aggregation (PA): PA was determined by the turbidimetric method of Born ${ }^{12}$ using a Chronolog. Copr. USA aggregometer. Aliquots of $400 \mu \mathrm{L}$ of a platelet suspension were transferred into small cuvettes and stirred at a constant speed of $180 \mathrm{~g}$ at $37^{\circ} \mathrm{C}$. The platelets were pre-incubated with different concentrations of GP or vehicle (saline) for $5 \mathrm{~min}$ at $37^{\circ} \mathrm{C}$, prior to the addition of $6 \mu \mathrm{MADP}$, $6 \mu \mathrm{M}$ epinephrine or $4 \mu \mathrm{g} / \mathrm{mL}$ collagen. The degree of aggregation (\%) was recorded continually for $5 \mathrm{~min}$ after the addition of the agonists.

Measurement of platelet ATP secretion induced by Collagen: platelet ATP secretion (\%) was evaluated using the luciferin/luciferase system described by IngermanWojenski \& Silver. ${ }^{13}$ The platelets were pre-incubated with different concentrations of GP or vehicle (saline) for $5 \mathrm{~min}$ at $37^{\circ} \mathrm{C}$, prior to the addition of $4 \mu \mathrm{g} / \mathrm{mL}$ collagen.

Measurement of Blood Coagulation: nine parts of blood drawn by venipuncture were mixed with one part of $3.8 \%$ trisodium citrate. Blood was centrifuged for $10 \mathrm{~min}$ at $900 \mathrm{~g}$ and the plasma stored at $-20^{\circ} \mathrm{C}$ until use. Activated prothrombin time (PT), activated partial thromboplastin time (APTT) and thrombin time (TT) were evaluated according to the method described by Triplett et al. ${ }^{14}$ Plasma was pre-incubated with $\mathrm{GP}$ or vehicle (saline) for $180 \mathrm{sec}$. at $37^{\circ} \mathrm{C}$ and coagulation time was measured using a Net Lab Digital Coagulation System.

\section{Results}

The platelet aggregation profile was tested with three different aggregating agents ( $6 \mu \mathrm{M}$ ADP, $6 \mu \mathrm{M}$ epinephrine and $4 \mu \mathrm{g} / \mathrm{mL}$ Collagen) in PRP pre-treated with increasing concentrations of GP and incubated during $5 \mathrm{~min}$ at $37^{\circ} \mathrm{C}$. The effects of GP on platelet aggregation are shown in Table 1.

The aggregation effects of all agonists were diminished in the presence of GP. From $125 \mu \mathrm{g} / \mathrm{mL}$ of GP onwards, the aggregation was significantly inhibited when compared to the control. The most significant effect was observed at a concentration of $500 \mu \mathrm{g} / \mathrm{mL}$ of GP.

Table 1. Effects of glyphosate (GF) on platelet aggregation induced by $6 \mu \mathrm{M}-\mathrm{ADP}, 6 \mu \mathrm{M}$-Epinephrine and $4 \mu \mathrm{g} / \mathrm{mL}$-Collagen. Platelets were pre-incubated with GP for $5 \mathrm{~min}$ at $37^{\circ} \mathrm{C}$ before stimulation

\begin{tabular}{cccc}
\hline Treatment & ADP (\%) & Epinephrine (\%) & Collagen (\%) \\
\hline Control (saline) & $86.3 \pm 2.7$ & $92.0 \pm 6.4$ & $75.2 \pm 9.8$ \\
Glyphosate & $75.6 \pm 1.6$ & $74.0 \pm 7.4$ & $62.8 \pm 10.2$ \\
$50 \mu \mathrm{g} / \mathrm{ml}$ & & $31.8 \pm 0.8^{*}$ & $29.6 \pm 6.1^{*}$ \\
$125 \mu \mathrm{g} / \mathrm{ml}$ & $47.6 \pm 4.0^{*}$ & $15.6 \pm 2.1^{*}$ & $7.6 \pm 3.3^{*}$ \\
$500 \mu \mathrm{g} / \mathrm{ml}$ & $20.3 \pm 2.9^{*}$ & 15.6
\end{tabular}

ADP - Adenosine diphosphate. $P$ value is calculated using the Tukey Kramer test $(n=10) ;{ }^{*} p<0.05$

Table 2. Effects of glyphosate (GF) on ATP platelet secretion stimulated by $4 \mu \mathrm{g} / \mathrm{mL}$-Collagen

\begin{tabular}{cc}
\hline Treatment & ATP-secretion (\%) \\
\hline Control (saline) & $100 \pm 0.0$ \\
Glyphosate $50 \mu \mathrm{g} / \mathrm{ml}$ & $74.5 \pm 3.7^{*}$ \\
$125 \mu \mathrm{g} / \mathrm{ml}$ & $30.8 \pm 5.6^{*}$ \\
$500 \mu \mathrm{g} / \mathrm{ml}$ & $1.2 \pm 0.1^{*}$ \\
\hline
\end{tabular}

ATP - Adenosine triphosphate. $P$ value is calculated using the Tukey Kramer test $(n=10) ;{ }^{*} p<0.05$

Table 3. Effects of glyphosate (GF) $(500 \mu \mathrm{g} / \mathrm{mL})$ on prothrombin time (PT), partial thromboplastin time (APTT) and thrombin time (TT). Each value represents the mean \pm SD of 10 independent experiments

\begin{tabular}{cc}
\hline Test/ Treatment & Time(s) \\
\hline PT/Control & $13.16 \pm 0.16$ \\
GF-500 $\mu \mathrm{g} / \mathrm{mL}$ & $12.9 \pm 0.14$ \\
APTT/Control & $31.34 \pm 0.63$ \\
GF-500 $\mu \mathrm{g} / \mathrm{mL}$ & $31.25 \pm 0.52$ \\
TT/Control & $17.0 \pm 0.13$ \\
GF-500 $\mu \mathrm{g} / \mathrm{mL}$ & $18.0 \pm 0.07$ \\
\hline
\end{tabular}

GF - glyphosate; PT - prothrombin time; APTT - partial thromboplastin time; TT - thrombin time. $P$ value is calculated using the Tukey Kramer test $(n=10)$. 
A decreased production of ATP was observed from the GP-treated platelets after stimulation with $4 \mu \mathrm{g} / \mathrm{mL}$ collagen as is demonstrated in Table 2. A significant decrease in ATP secretion was already observed at a concentration of $50 \mu \mathrm{g} / \mathrm{mL}$ of GP when compared to the control. The maximum inhibition was observed with $500 \mu \mathrm{g} / \mathrm{mL}$ of GP.

The blood coagulation profile was based on the results of prothrombin time (PT), thromboplastin time (APTT) and thrombin time (TT) (Table 3). The samples were incubated with a high concentration of GP $(500 \mu \mathrm{g} / \mathrm{mL})$ for 3 minutes at $37^{\circ} \mathrm{C}$ before stimulating clotting. None of the three parameters was affected by the glyphosate under experimental conditions even at such a high concentration.

\section{Discussion}

Glyphosate (GP) is the active ingredient in the most widely used herbicide in the world and has been chiefly studied by weed control and laboratory bioassays. We showed previously that long-term treatment of rats with low doses of Glyphosate-Biocarb ${ }^{\circledR}$ may induce hepatic histological changes, the leakage of hepatic intracellular enzymes as well as nasal bleeding without decreasing platelet counts. ${ }^{11}$ The objective of the current study was to determine in vitro whether GP would affect platelet function and coagulation.

Human blood platelets were incubated in the presence of GP for 5 minutes at $37^{\circ} \mathrm{C}$. The effect of GP on platelet aggregation is shown in Table 1. Treatment with $500 \mu \mathrm{g} / \mathrm{mL}$ of GP was enough to exhibit significant inhibition by three types of agonists [ADP (79.7\%), epinephrine (84.4\%) and collagen (89.8\%)]. The inhibitory effect was dose dependent for concentrations of between 50 and $500 \mu \mathrm{g} / \mathrm{mL}$. The results demonstrate that GP promoted changes in the platelet metabolism with an inhibitory effect on primary hemostasis. This can explain previous observations of hemorrhagic effects after exposure of rats to GP.

Platelet activation occurs in two stages following the addition of agents such as ADP, epinephrine and collagen. The primary phase of platelet activation by ADP is characterized by shape change and platelet aggregation. This is followed by a second phase which includes the release of dense granule contents, such as 5-HT, ADP and ATP, that potentiate platelet aggregation. ${ }^{15,16}$ In this study, we observed that shape change and the primary phase induced by the three agonists were not affected by the presence of GP. On the other hand, the second phase was significantly inhibited.

ATP production was used as an index of platelet secretion capacity. We observed decreased secretion of ATP by platelets pre-treated with GF (Table 2) after stimulation with collagen. The maximum inhibition was observed at $500 \mu \mathrm{g} / \mathrm{mL}$ of GP. These results suggest that inhibition of granule release may be the mechanism involved in the antiaggregation effect caused by GP.
The influence of different pesticides on the platelet metabolism and blood coagulation has been studied. ${ }^{17-20} \mathrm{Krug}$ and Berndt ${ }^{17}$ demonstrated that carbamate-type pesticides inhibited platelet aggregation and the formation of thromboxane $\mathrm{B}_{2 \cdot}$. Lox ${ }^{18}$ demonstrated that the insecticide malathion affects blood coagulation in rats. Furthermore, pesticides produce both hypertension and cardiac arrhythmias. ${ }^{21}$

In the current study, screening tests were carried out in relation to the activated prothrombin time (PT), activated partial thromboplastin time (APTT) and thrombin time (TT) to evaluate the effects of GP on blood coagulation enzymes. A high concentration of GP $(500 \mu \mathrm{g} / \mathrm{mL})$ did not prolong the clotting time of three parameters evaluated under experimental conditions. It is worth noting that preincubation of plasma at the maximum dosage $(500 \mu \mathrm{g} / \mathrm{mL})$ did not promote inhibitory action on fibrinogen (TT); additionally, it did not have an inhibitory effect upon the activity of the other plasma proteins (as measured by PT and APTT) as shown in Table 3.

\section{Conclusion}

These effects suggest that GP activity in human blood is limited to primary hemostasis. Since reduced platelet function can play an important role as an adverse effect, further experiments will be needed to elucidate the biochemical platelet alterations which are associated to the capacity of GP to inhibit ATP secretion and platelet aggregation. In conclusion, the results demonstrate that GP caused changes in the platelet metabolism with an inhibitory effect on primary hemostasis.

\section{Resumo}

O glifosato [N-(phosphonomethyl)-glycine] é um herbicida pósemergente não seletivo de amplo espectro muito utilizado na agricultura. Dados da literatura referentes aos efeitos desse produto na saúde humana são contraditórios. Em estudos prévios demonstramos que ratos previamente tratados com glifosato apresentavam lesões hepáticas e sangramento sem alterações quantitativas de plaquetas. O objetivo do presente estudo é investigar os efeitos in vitro do glifosato (GP) na agregação plaquetária e coagulação sanguínea em humanos. A agregação plaquetária foi determinada em plasma rico em plaquetas (PRP) usando os agentes adenosina difosfato (ADP) $6 \mu \mathrm{M}$, epinefrina $6 \mu \mathrm{M}$ e colágeno $4 \mu \mathrm{g} / \mathrm{mL}$. Prétratamento com GP $500 \mu \mathrm{g} / \mathrm{mL}$ demonstrou significativa hipofunção dos três agentes agregantes. O efeito inibitório foi dose dependente em concentrações de 50-500 $\mu \mathrm{g} / \mathrm{mL}$. Utilizando-se a quantificação de ATP como um índice da capacidade de secreção plaquetária, foi observado diminuição da liberação das plaquetas tratadas com GP. Por outro lado, o GP não promoveu efeito inibidor no tempo de protrombina (TP), tempo de tromboplastina parcial ativada (ATTP) e tempo de trombina (TT). Em conclusão, os resultados demonstram que o GP promove mudanças no metabolismo plaquetário com 
efeito inibitório na hemostasia primária. Rev. Bras. Hematol. Hemoter. 2010;32(4):291-294.

Palavras-chave: Glifosato; agregação plaquetária; secreção plaquetária; coagulação sanguínea; resistência ao herbicida.

\section{REFERENCES}

1. Coutinho CFB, Tanimoto ST, Galli AG, Gustavo S, Takayama MA, Raquel B, et al. Pesticides: action mechanism, degradation and toxicity. Pesticidas. 2005;15:65-72.

2. Smith EA, Oehme FW. The biological activity of glyphosate to plants and animals: a literature review. Vet Hum Toxicol. 1992; 34(6):531-43.

3. Lee CH, Shih CP, Hsu KH, Hung DZ, Lin CC. The early prognostic factors of glyphosate-surfactant intoxication. Am J Emerg Med. 2008;26(3):275-8.

4. Trapé AZ. Occupational exposure to glyphosate formulations. Rev Bras Toxicol. 2005;18:114-6.

5. Williams GM, Kroes R, Munro IC. Safety evaluation and risk assessment of the herbicide Roundup and its active ingredient, glyphosate, for humans. Regul Toxicol Pharmacol. 2000; 31(2 Pt 1):117-65.

6. Dallegrave E, Mantese FD, Coelho RS, Pereira JD, Dalsenter PR, Langeloh A. The teratogenic potential of the herbicide glyphosateRoundup in Wistar rats. Toxicol Lett. 2003;142(1-2):45-52.

7. Marc J, Bellé R, Morales J, Cornier P, Mulner-Lorillon O. Formulated glyphosate ativates the DNA-response checkpoint of de cell cycle leading to the prevention of G2/M transition. Toxicol Sci. 2004; 82(2):436-42.

8. Marc J, Mulner-Lorillon O, Bellé R. Glyphosate-based pesticides affect cell cycle regulation.. Biol Cell. 2004; 96(3):245-9.

9. Amerio P, Motta A, Toto P, Pour SM, Pajand R, Feliciani C, et al. Skin toxicity from glyphosate-surfactante formulation. J Toxicol Clin Toxicol. 2004;42(3):317-9.

10. De Roos AJ, Zahm SH, Cantor KP, Weisemburger DD, Holmes FF, Burmeister LF, et al. Integrative assessment of multiple pesticides as risk factors for non-Hodkin's lymphoma among men. Occup Environ Med. 2003;60(9):E11.

11. Benedetti AL, Vituri C de L, Trentin AG, Domingues MA, AlvarezSilva M. The effects of sub-chronic exposure of Wistar rats to the herbicide Glyphosate-Biocarb. Toxicol Lett. 2004;153(2):227-32.
12. Born GVR, Cross MJ. The aggregation of blood platelets. J Physiol. 1963;168:178-95.

13. Ingerman-Wojenski CM, Silver MJ. A quick method for screening platelet dysfunctions using the whole blood lumi-aggregometer. Thromb Haemost. 1984;51(2):154-6.

14. Triplett DA, Harms CS, Koepke JA. The effect of heparin on the activated partial thromboplastin time. Am J Clin Pathol. 1978; (3 Suppl):556-9.

15. Harrison P. Platelet function analysis. Blood Rev. 2005;19:11123.

16. Skrabanja AT, Bouman EA, Dagnelie PC. Potential value of adenosine 5-triphosphate (ATP) and adenosine in anaesthesia and intensive care medicine. Br J Anaesth. 2005;94(5):556-62.

17. Krug HF, Berndt J. Inhibition by pesticides of prostaglandin formation in blood platelets. Blut. 1985;51(1):19-23.

18. Lox CD. Effects of acute pesticide poisoning on blood clotting in the rat. Ecotoxicol Environ Saf. 1983;7(5):451-54.

19. Muzi G, Locati EH, Murgia N, Ambrosio G, Abbritti G. Evaluation of the effects of occupational noxae on the cardiovascular system. Med Lav. 2004;95(2):145-57.

20. Quistad GB, Casida JE. Sensitivity of blood-clotting factors and digestive enzymes to inhibition by organophosphorus pesticides. $\mathrm{J}$ Biochem Mol Toxicol. 2000;14(1):51-6.

21. Blair A, Sandler DP, Tarone R, Lubin J, Thomas K, Hoppin JA, et al. Mortality among participants in the agricultural health study. Ann Epidemiol. 2005;15(4):279-85.

Avaliação: Editor e dois revisores externos

Conflito de interesse: sem conflito de interesse

Recebido: 05/11/2009

Aceito após modificações: 08/06/2010 